\title{
THE METHODS OF CORRECTING A SENTENCE WHEN EXECUTED BY THE COURT
}

\author{
Viktor I. Kachalov \\ Russian State University of Justice of N.V. Radutnaya, Moscow, Russian Federation
}

Introduction: the court performing its criminal procedure activities in the execution of a sentence through the judicial control, corrects the legally effective sentence. The court may not interfere in the gist of the legally effective sentence. The correction of the sentence can only involve partial changes, alterations, amendments, clarifications, and filling of the court decision entered into legal force. Only those provisions that do not affect the gist of the sentence and do not affect its legality, validity and justice may be subject to the change, quashing, or reprieve. The methods of correcting the sentence take on particular significance; in this connection, the author sets the purpose of determining the methods of correcting the sentence by the court and their scientific classification. Methods: the methodological framework for this study is a set of scientific methods, among which the main place is occupied by Aristotelian method, the methods of analysis and synthesis. Results: based on the analysis of the criminal procedure rules and the practice of their application there were determined the methods of correcting the sentence in its execution by the court, proposed a scientific classification of these methods based on different grounds. Conclusions: the result of the study proved that the types of corrections of the sentence can be its partial changes, quashing, reprieve, as well as its partial correction, amendment, clarification and filling. Each of these methods constitutes its own system of actions, used only in the execution of a particular type of punishment. All the methods of correcting the sentence can be divided into several groups, based on such criteria as the nature of the action of the court, the sector specific gist, the relationship with the behavior of the convict, the degree of impact on the sentence.

Key words: correction of a sentence, methods of corrections, execution of a sentence, quashing of a sentence, reprieve of a sentence, the change of conditions of serving a sentence.

УДК 343.152

ББК 67.410 .2

\section{СПОСОБЫ КОРРЕКТИРОВКИ СУДОМ ПРИГОВОРА ПРИ ЕГО ИСПОЛНЕНИИ}

\author{
Виктор Иванович Качалов \\ Российский государственный университет правосудия им. Н.В. Радутной, г. Москва, Российская Федерация
}

Введение: суд, осуществляя уголовно-процессуальную деятельность при исполнении приговора посредством судебного контроля, корректирует вступивший в законную силу приговор. При этом суд не вправе вмешиваться в сущность вступившего в законную силу приговора. Корректировка приговора может быть связана только с частичными изменениями, исправлениями, поправками, разъяснениями и восполнениями вступившего в законную силу судебного решения. Изменению, отмене или замене могут быть подвергнуты только те положения, которые не затрагивают существо самого приговора, не касаются вопросов его законности, обоснованности и справедливости. Важное значение приобретают способы корректировки приговора, в связи с чем автором поставлена цель определения способов судом корректировки приговора и их научной классификации. Методы: методологическую основу данного исследования составляет совокуп艛 ность методов научного познания, среди которых основное место занимают формально-логический метод, а также методы анализа и синтеза. Результаты: на основе анализа уголовно-процессуальных норм и практики их применения автором выявлены способы корректировки приговора судом при его исполнении, предложена научная классификация данных способов, базирующаяся на различных основаниях. Выводы: в резуль- 
тате исследования установлено, что к видам корректировки приговора могут быть отнесены его частичное изменение, отмена, замена, а также частичное исправление, поправка, разъяснение и восполнение. Каждый из этих способов образует свою систему действий, применяемых только при исполнении конкретного вида наказания. Все способы корректировки приговора могут быть разделены на несколько групп, в основании которых лежат такие критерии, как характер действий суда, отраслевое содержание, взаимосвязь с поведением осужденного, степень воздействия на приговор.

Ключевые слова: корректировка приговора, способы корректировки, исполнения приговора, отмена наказания, замена наказания, изменение условий отбывания наказания.

\section{Введение}

Суд, осуществляя уголовно-процессуальную деятельность при исполнении приговора посредством судебного контроля, корректирует вступивший в законную силу приговор. При этом суд не вправе вмешиваться в сущность вступившего в законную силу приговора. Корректировка последнего может быть связана только с частичными изменениями, исправлениями, поправками, разъяснениями и восполнениями вступившего в законную силу судебного решения. Изменению, отмене или замене могут быть подвергнуты только те положения, которые не затрагивают существо самого приговора, не касаются вопросов его законности, обоснованности и справедливости. При корректировке приговора суд не вправе изменять формулировку обвинения, фактические обстоятельства уголовного дела, квалификацию преступления, меру наказания и т. д. В противном случае он фактически подменяет собой вышестоящий суд, который в соответствии с п. 4 ч. 1 ст. 29 УПК РФ и гл. $47^{1}$ и $48^{1}$ УПК РФ осуществляет полномочия по отмене или изменению решений, принятых нижестоящим судом. Ключевым критерием, разграничивающим возможность рассмотрения вопросов, связанных с некорректностью приговора, вышестоящим судом либо в порядке исполнения приговора является возможность суда затронуть существо приговора. Термин «существо приговора» был сформулирован в п. 2 Постановления Пленума Верховного Суда СССР от 22 декабря 1964 г. № 18 «О некоторых процессуальных вопросах, возникших в судебной практике при исполнении приговоров» $[3$, с. 8,9 ; 6, с. 616]. В.В. Николюк совершенно справедливо указывает, что в первую очередь «в порядке исполнения приговора по замыслу законодателя, должны исправляться допущенные нижестоящим судом очевидные ошибки технического характера, которые не касаются существа приговора» $[4$, c. 78$]$.

В настоящее время термин «существо приговора» определен в п. 22 Постановления Пленума Верховного Суда РФ от 20 декабря 2011 г. № 21 «О практике применения судами законодательства об исполнении приговора» [5]. В соответствии с ним сомнения и неясности, возникающие при исполнении приговора, не должны не только затрагивать существо приговора, но и влечь ухудшение положения осужденного. Полагаем, что это правило распространяется на все виды и способы корректировки приговора.

Корректировке при исполнении приговора подлежат только те вопросы, которые вытекают из порядка исполнения наказания, а также из порядка отбывания наказания осужденным. Это обусловлено тем, что приговор уже вступил в законную силу. Поэтому любое вмешательство, которое не связано с порядком исполнения наказания, может считаться вмешательством в сущность приговора.

\section{Виды корректировки приговора}

Частичное изменение, отмена, замена, а также частичное исправление, поправка, разъяснение и восполнение, которым может быть подвергнут приговор в результате его исполнения, представляют собой способы корректировки приговора, вступившего в законную силу. Каждый из этих способов образует свою систему действий, применяемых только при исполнении конкретного вида наказания.

В силу того, что корректировке подвергается приговор, вступивший в законную силу, а одним из важнейших его элементов является назначенное наказание (ч. 5 ст. 302 УПК РФ), то корректировке при исполнении приговора чаще всего подвергается назначенное 
наказание. Возможность корректировки приговора заложена в самой правовой природе целей уголовного наказания. В соответствии с ч. 2 ст. 43 УК РФ наказание применяется не только в целях восстановления социальной справедливости, но и в целях исправления осужденного. А исправление осужденного может быть достигнуто не только в процессе полного исполнения и отбывания назначенного наказания, но и на ранних этапах его отбывания. В случаях, когда цели наказания не достигнуты в связи со злостным уклонением лица от его отбывания, частичная корректировка наказания направлена в сторону его усиления. Например, в случае злостного уклонения от отбывания наказания в виде штрафа (в соответствии со ст. 46 УК РФ), в случае злостного уклонения от отбывания исправительных работ (в соответствии со ст. 50 УК РФ), в случае злостного уклонения от отбывания ограничения свободы (в соответствии со ст. 53 УК РФ) и т. д. суд осуществляет корректировку приговора в сторону усиления лицу уголовного наказания.

Так, Жуковский районный суд Брянской области удовлетворил представление судебного пристава-исполнителя Жуковского РО СП УФССП по Брянской области А. о замене наказания в виде штрафа по приговору Канашского районного суда Чувашской Республики от 10 декабря 2014 г., постановленному в отношении Ф., на более строгий вид наказания - в виде исправительных работ сроком на один год с удержанием из заработной платы осужденного 20 процентов в доход государства ежемесячно. Однако Ф. назначенное наказание не исполнил, при этом с ходатайством о рассрочке уплаты штрафа он не обращался, каких-либо данных, свидетельствующих об уважительности причин неуплаты штрафа, не представил. На основании изложенного суд считает осужденного Ф. злостно уклоняющимся от уплаты штрафа [1].

Содержание наказания определяется нормами уголовного и уголовно-исполнительного законодательства РФ. Поэтому основные способы корректировки приговора вытекают из норм уголовного и уголовно-исполнительного законодательства РФ. Вместе с тем некоторые из этих способов предопределены нормами уголовно-процессуального законодательства РФ.

\section{Классификация способов корректировки приговора}

Полагаем, что все способы корректировки приговора условно можно классифицировать по следующим основаниям:

1. По правовой природе и отраслевому содержанию:

a) уголовно-правовые способы, которые базируются на нормах уголовного законодательства РФ (замена наказания; условно-досрочное освобождение от наказания; отмена условнодосрочного освобождения; замена неотбытой части наказания более мягким видом наказания; отмена условного осуждения или продление испытательного срока и др.);

б) уголовно-исполнительные способы, нашедшие свое отражение в нормах уголовно-исполнительного законодательства РФ (снижение размера удержания из заработной платы осужденного к исправительным работам; замена неотбытой части наказания более мягким видом наказания либо освобождение от наказания в виде ограничения по военной службе военнослужащего, уволенного с военной службы);

в) уголовно-процессуальные способы, которые заложены в нормах УПК РФ (разрешение вопросов об исполнении приговора при наличии других неисполненных приговоров; зачет времени содержания под стражей, а также времени пребывания в лечебном учреждении в наказание; разъяснение сомнений и неясностей, возникающих при исполнении приговора).

2. В зависимости от взаимосвязи с поведением осужденного, в отношении которого подлежит корректировке приговор:

a) объективные - не зависящие от осужденного, а детерминированные внешними факторами (освобождение от наказания или смягчение наказания вследствие издания уголовного закона, имеющего обратную силу; разъяснение сомнений и неясностей, возникающих при исполнении приговора; зачет времени содержания под стражей, а также времени пребывания в лечебном учреждении в срок наказания и т. д.);

б) субъективные - детерминированные поведением осужденного (заключение под стражу осужденного, скрывшегося в целях 
уклонения от отбывания наказания в виде штрафа, обязательных работ, исправительных работ либо ограничения свободы; заключение под стражу осужденного к лишению свободы с отбыванием наказания в колонии-поселении, не прибывшего к месту отбывания наказания в установленный срок и др.);

в) объективно-субъективные - зависящие не только от самого осужденного, но и от внешних факторов (замена наказания в случае злостного уклонения от его отбывания; условно-досрочное освобождение от отбывания наказания и т. д.).

3. По степени воздействия на приговор:

a) общие способы, которые действуют на весь приговор, подлежащий исполнению (условно-досрочное освобождение от отбывания наказания; освобождение от наказания в связи с болезнью осужденного; отмена условно-досрочного освобождения и т. д.).

К таким видам корректировки относится и замена вида уголовного наказания. Замена наказания может осуществляться в случае злостного уклонения от его отбывания осужденным (п. 2 ст. 397 УПК РФ), а также при замене неотбытой части наказания более мягким видом наказания в соответствии со ст. 80 УК РФ (п. 5 ст. 397 УПК РФ). Так, при исполнении приговора Ульяновского областного суда от 12 мая 2012 г., вынесенного в отношении В., осужденного по п. «В» ч. 5 ст. 290 УК РФ за получение взятки, с назначением наказания в виде штрафа в размере 7500000 рублей, был подвергнут изменению вступивший в законную силу приговор. Основанием изменения приговора послужило злостное уклонение осужденного от исполнения приговора суда. Имея жилой дом, земельный участок и два автомобиля, арест на которых не накладывался, осужденный В., реализовав автомобили, не внес вырученные денежные средства в уплату штрафа, распорядился денежными средствами по своему усмотрению. Никаких мер к реализации недвижимого имущества, находящегося у него в собственности, не предпринял. При таких обстоятельствах суд при исполнении приговора принял решение об удовлетворении представления замене не отбытого В. основного наказания в виде штрафа на лишение свободы сроком на два года с отбыванием наказания в исправительной колонии строгого режима [2].

б) специальные способы, которые действуют на некоторую часть приговора (разъяснения сомнений и неясностей, возникающих при исполнении приговора; снижение размера удержания из заработной платы осужденного к исправительным работам и т. д.). Исправление, восполнение приговора при его исполнении возможно при наличии незначительных дефектов, которые имеют место во вступившем в законную силу приговоре. К таким дефектам можно отнести: отсутствие указаний в приговоре на зачет предварительного заключения, отсутствие решения судьбы вещественных доказательств, неправильно указанная фамилия осужденного, случаи неопределения размера и распределения процессуальных издержек и т. д. Они объективны по отношению к личности осужденного, назначенному наказанию и т. д. Иные вопросы не подлежат разрешению судом в порядке исполнения приговора. Так, суд апелляционной инстанции постановление Волжского городского суда Волгоградской области от 19 мая 2014 г. отменил, производство по заявлению А. прекратил. Заявитель А. обратился в суд с заявлением о возврате ему телефона и оспаривал право собственности на указанный телефон. Несмотря на то что заявитель фактически оспаривал законность и обоснованность приговора в этой части, судья рассмотрела заявление А. о возврате имущества, изъятого в ходе рассмотрения уголовного дела, в порядке исполнения приговора, предусмотренном ст. 397 УПК РФ.

4. По характеру действий суда:

a) отмена наказания (условно-досрочное освобождение от отбывания наказания в соответствии со ст. 79 УК РФ (п. 4 ст. 397 УПК РФ); освобождение от наказания в связи с болезнью осужденного в соответствии со ст. 81 УК РФ (п. 6 ст. 397 УПК РФ и др.);

б) замена наказания (замена наказания в случае злостного уклонения от его отбывания и др.);

в) изменение условий отбывания наказания (продление испытательного срока, снижение размера удерживаемой заработной платы, отмена либо дополнение возложенных на 
осужденного обязанностей в соответствии со ст. 73 УК РФ (п. 8 ст. 397 УПК РФ) и т. д.).

Обстоятельства, которые становятся основаниями для корректировки приговора посредством его изменения, отмены, замены либо освобождения осужденного от наказания, должны иметь статус юридически значимых фактов и быть оформлены надлежащим образом в соответствии с действующим законодательством. К примеру, осужденное лицо в соответствии с ч. 4 ст. 116 УИК РФ может быть признано злостным нарушителем установленного порядка отбывания наказания постановлением начальника исправительного учреждения по представлению администрации исправительного учреждения одновременно с наложением взыскания.

\section{Выводы}

Таким образом, к видам корректировки приговора могут быть отнесены его частичное изменение, отмена, замена, а также частичное исправление, поправка, разъяснение и восполнение. Каждый из этих способов образует свою систему действий, применяемых только при исполнении конкретного вида наказания.

Bce способы корректировки приговора могут быть разделены на несколько групп, в основании которых лежат такие критерии, как характер действий суда, отраслевое содержание, взаимосвязь с поведением осужденного, степень воздействия на приговор. Обстоятельства, которые становятся основаниями для корректировки приговора посредством его изменения, отмены, замены либо освобождения осужденного от наказания, должны иметь статус юридически значимых фактов.

\section{СПИСОК ЛИТЕРАТУРЫ}

1. Архив Жуковского районного суда Брянской области. -2017. 2012.
3. Квициния, Д. А. Разрешение судом сомнений и неясностей, возникающих при исполнении приговора : автореф. дис. ... канд. юрид. наук / Квициния Диана Аполлоновна. - М., 2012. - 28 с.

4. Николюк, В. В. Устранение судом сомнений и неясностей, обнаруживающихся при исполнении приговора / В. В. Николюк // Российское правосудие. - 2017. - № 3 (130). - С. 76-86.

5. Постановление Пленума Верховного Суда РФ «О практике применения судами законодательства об исполнении приговора» от 20 дек. 2011 г. № 21. - Доступ из справ.-правовой системы «КонсультантПлюс».

6. Сборник постановлений Пленума Верховного Суда СССР (1924-1973). - М. : Известия Советов Депутатов Трудящихся СССР, 1974. - 758 с .

\section{REFERENCES}

1. Arkhiv Zhukovskogo rayonnogo suda Bryanskoy oblasti. 2017 [The Archive of the Zhukovsky District Court of the Bryansk Region. 2017].

2. Arkhiv Ulyanovskogo oblastnogo suda. 2012 [Archive of the Ulyanovsk Regional Court. 2012].

3. Kvitsiniya D.A. Razreshenie sudom somneniy $i$ neyasnostey, voznikayushchikh pri ispolnenii prigovora: avtoref. dis. ... kand. yurid. nauk [Resolution by Court of Doubts and Ambiguities Arising at Sentence Execution. Cand. jurid. sci. abs. diss.]. Moscow, 2012. 28 p.

4. Nikolyuk V.V. Ustranenie sudom somneniy $i$ neyasnostey, obnaruzhivayushchikhsya pri ispolnenii prigovora [Elimination by Court of Doubts and Ambiguities Arising at Sentence Execution]. Rossiyskoe pravosudie, 2017, no. 3 (130), pp. 76-86.

5. Postanovlenie Plenuma Verhovnogo Suda $R F$ «O praktike primeneniya sudami zakonodatelstva ob ispolnenii prigovora» ot 20 dekabrya 2011 g. № 21 [The Resolution of the Plenum of the Russian Federation Supreme Court "On the Practice of Application by Courts of the Legislation on Sentence Execution" of December 20, 2011 no. 21]. Access from Reference Legal System "KonsultantPlyus".

6. Sbornik postanovleniy Plenuma Verkhovnogo Suda SSSR (1924-1973) [Collection of Resolutions of Plenum of the Supreme Court of the USSR (1924-1973)]. Moscow, Izvestiya Sovetov Deputatov Trudyashchihsya SSSR, 1974. 758 p. 


\section{Information about the Author}

Viktor I. Kachalov, Candidate of Juridical Sciences, Associate Professor, Professor, Department of Criminal Procedure Law, Russian State University of Justice of N.V. Radutnaya, Novocheremushkinskaya St., 69, 117418 Moscow, Russian Federation, okukel@yandex.ru.

\section{Информация об авторе}

Виктор Иванович Качалов, кандидат юридических наук, доцент, профессор кафедры уголовно-процессуального права, Российский государственный университет правосудия им. Н.В. Радутной, ул. Новочеремушкинская, 69, 117418 г. Москва, Российская Федерация, okukel@yandex.ru. 